\title{
Portrayal of Death in Selected Poems of Rossetti and Mahwee (A Comparative-Literary Study)
}

\author{
Salar Mahmud Muhamad Salih \\ Department of English, College of Education, University of Garmian
}

\begin{abstract}
Comparative literature came into being early in the Nineteenth century when the discourse of national literatures arose to vital prominence. It shows the value and importance of encountering literature from outside one's own culture. The paper tries to trace the portrayal and significance of the theme of death in selected poems of both Christina Rossetti (1830-1894) who was one of the leading female poets of the Victorian era in English literature and Mahwee (1830-1906) who is regarded one of the most outstanding Kurdish poets from Kurdistan of Iraq.

Accepting death as a part of life is explicitly depicted in the selected poems, especially since the two poets are Muslims and Christians and believed in the afterlife besides their dwelling on intellectual and religious pursuits, and contemplating the soul and the eternal hereafter. Thus, the study hypothesizes the existence of resembling and close thematic scenes of death showed by both poets, who nearly lived in the same century, in spite of the ir different religions, nations, and cultures. Also, it adopts the form of the literary theorist Ihab Hassan (1925-2015) concerning the American school for comparative literature to tackle the topic following MLA system of documentation, and it ends up with a conclusion and list of works cited.
\end{abstract}

\section{Introduction}

Death is one of the most frequently treated subjects in literature, and it's presented as a theme, symbol, or plot device that exists as one of the defining elements in the writing of poets, dramatists, and novelists. It is also reticulated with the origins of literature itself. Human consciousness of mortality has for centuries provided the impetus for reflection on the causes, meaning, and nature of existence.

American School of comparative literature is named as the school of "parallel study". In the 1950s, a group of American scholars did not follow the influence study of the French School, but opened a new path through American comparative literature theories and practices, and compared any two pieces of literatures (such as English \& Kurdish) without direct influences and compared literature with other disciplines. It largely broadened the horizon of comparative study, and exerted profound influences globally. Henry Remark (1916 - 2009) regarded the American school of comparative literature and Paralle lism theory as not only a comparison of one literature to another or others, but also with other spheres of human experience like history, arts, philosophy and social sciences (31). 
Also ,the Arab-American literary theorist and critic Ihab Hassan (1925 - 2015), as he is mentioned earlier, alluded to the fact that there are intimated relationships between literatures of different people regardless to any mutual influence or direct relation between them. This because of the fact that human mind has common ways of responding to experience and two authors may have the same cast of mind, in addition to the equivalent surrounding circumstances such as the reactions of death in accordance to their religious, cultural, and social settings and traditions $(27,28)$.

Thus, the American comparative school is portrayed through studying literatures from a global perspective and under the multicultura lism context, cross culture, tradition, country, nation and language, and a new dialogue for international comparative literature is built to have a theoretical foundation for its new pattern (Hassan 30).

\section{About the Poets}

Christina Georgina Rossetti (1830-1894) was born in December 1830, into a Victorian family of poets and artists. She is considered as one of the most significant women poets of the 19th Century strictly the Victorian era. She rejected a couple of offers for marriage because of religious differences (Thornley \& Roberts 109). The main topic of her poetry is religion, though she wrote some passionate love-poetry much of which celebrates the joy of the natural world. She was close to her brother Dante Gabriel Rossetti (1828-1882) who was the most musical poet in English poetry during the Victorian era, and she was linked through him with the Pre-Raphaelite movement in art. After his death, she lived a sheltered life. She died due to cancer in December 1894 (Ibid 127).

The Kurdish poet, Mala Mahmud Mala Osman Balkhi known as Mahwee was born in 1830 in Sulaymanyah, Kurdistan, Iraq. He was a very calm and genius person. He started studying religious principles since his early childhood in the mosques and till 1862, then he became a preacher in one of the mosques in Baghdad. Later, he went to Mecca for pilgrimage and after that he travelled to Istanbul in 1883 (Sajjadi 355). He tended to write poems on Sufism more than any other trends due to his earlier background in the terms of religious learning and teaching.

He also had inclinations in complaining against the life struggles and the time that passed in vain without having a segment of remaining time even to die in. He went on writing pessimistic poems concentrating on death and the life after death and optimistic ones since he was Muslim and believed in the life after death. In his last days, he decided to stay in his own shelter in Sulaimanyah to contemplate the philosophy of life till he passed away in 1904 (ibid 35).

\section{Death in Poetry of Both Rossetti and Mahwee}

Throughout her life Christina Rossetti was pursued by the thought of death. Many of her poems, especially her later poems, display her concerns about death. Her early poems show death as a mystery without clues and also as the destroyer of mortal things, reflecting her pessimism and her sometimes naturalistic views on life (Yang 12). Her persistent theme of death is an expression of the conflict between a sometimes skeptical, and sometimes religious views: The mystery of Life, the mystery

Of Death, I see

Darkly as in a glass; 
Their shadows pass

And talk with me.

(Lines 1-5)

Mahwee, on the contrary, was obsessed by the frame of death since his early phase of life; he was a sufi person. Sufism is a mystical Is lamic belief and practice in which Muslims seek to find the truth of divine love and knowledge through direct personal experience of God. It consists of a variety of mystical paths that are designed to ascertain the nature of humanity and of God and to facilitate the experience of the presence of divine love and wisdom in the world (Schimmel 32). So, Mahwee would rather prefer death upon the life and considers the bitterness of death more relaxed than the sweetness of life. Since he was a very pious Muslim, he summoned death as a rescuer to save him from the mortal temporary life, as he states (Osman 235):

Along with its extreme bitterness; Dear alive ones!

Juice of death is more honeyed than the sweet of life

Death is a bless in this loose untidy world

( lines 57-59)

Mahwee continues reckoning death as more precious than life, he viewed life as an absurd period that one day must vanish and that's meaningless and not worthy to try for. He blames those whom deeply involved with life and forget the eternal life, and he insists that only doomsday can remind us of itself, and considers life as a chaotic atmosphere (ibid 238):

The absurd imagination of life squeezes my mind and heart Doomsday! It's the only thing that can remind me of itself In this chaotic life we had better to leave in silent sound

(Lines 87-90)

Rossetti, like Mahwee, considers life as less significant than death, and she imagines an apocalypse in the language of magnitude in these cryptic and repetitive lines of her poem "The Face of the Deep", and in the event of final Judgment, human time will seem to be infinitely extended, but this apparent extension of temporality is collapsed into almost nothing, a tiny duration or "little while" that represents life, is "denied proportion" and transformed into another dimension entirely, she shows the shortness of life which seems longer for some (Harrison 495): Time lengthening, in the lengthening seemeth long;

But ended Time will seem a little space,

A little while from morn to evensong,

A little while that ran a rapid race,

A little while, when once Eternity

Denies proportion to the other's pace.

(Lines 1-6)

In an ironic tone, Mahwee asks for more life to find a chance for dying, this is an outstanding way of creating irony for displaying the greatness of death as a relief from the useless life that sometimes one spends it ruthlessly, so he asks God for extending his life so that he might 
have a better death with contribution of merited person in the life so that he makes both fruitful life and death alike, and he considers life like a mirage that passes rapidly and people understand it as a shape of water or a color of water if it has one! (Muddares \& Mala Karim 448). He also resembles death as a stone that can easily break the glass that stands for life. Thus, he considers death as close as shadow for human being than anything else, he states (Sleman 99):

My age has gone in vain and spent uselessly

O God, lengthen my life to die in merited people's shelter

As water we reckoned it while it was a mere mirage

All gone nothing but only a shape of water

Suddenly, death's stone breaks the glass of my life

Please, pour more wines, dear, the time does run

(Lines 3-8)

Rossetti's dual perception of things often led her to see the opposing qualities in a thing. Her sensitive eyes saw life as an initial stage in a continuum of death. Because she experienced daily death-in-life, conversely, she also believed in life after the actual death of a person as she was a Christian. This belief, however, looks like a wistful dream, as her uncertain, fluctuating tone designates. Especially in the case of her wistful dream of reunion with a person she loved, her unconfirmed attitude was more apparent (Harrison 499).

Rossetti asserts the negation of life on earth and the affirmation of death as a resting place, waiting for regeneration. It states the poet's extraordinary world view, which is filled with sad, unpleasant attitudes toward nature and its phenomena. And she denies even the happy, delirious movements of natural objects (Conley 386):

One day it will be sweet

To shut our eyes and die;

Nor feel the wild flowers blow, nor birds dart by

With flitting butterfly,

Nor grass grow long above our heads and feet,

Nor hear the happy lark that soars sky-high,

(Lines 20-25)

Regarding the image of death for the sake the beloved, Mahwee stated his desire for death as he became under the impact of her beauty which caused him die. This is a unique feeling from the poet to consider himself among the group of those who preferred death as a result of his extreme passionate for his love, and he dissolves and vanishes from the life into the eternal death and he describes her extreme beauty by resembling her as daffodils, he says (Mallaa 211):

When the heart defrosts for you, that day never passes

And when you shine as a sun, the heart vaporizes as a dew

Her face glides as daffodils when she turns

All the precious things bend and ask for wine or to withdraw

(Lines 11-14) 
Rossetti, from other side, does not concern with love as Mahwee, she only prefers the notion of death as a chance to escape from life not to sacrifice for the sake of someone beloved. She shows the close relationship that her desire to escape from her present world had with her frequent and fervent thoughts on the abstract world of death as a way of change as she states (Yang 48):

I am sick

of all I have and all I see

I am sick of self, and there

is nothing new

(Lines 11-14)

\section{Conclusion}

The study has concluded the following:

1. Death a part of life, and this is a general understanding for it from the two cultures.

2. In spite of their different religion, the two poets feel optimistic towards the death and the afterlife that follows.

3. Both prefer death upon life and see it as a salvation from the bitterness of their lives.

4. The two poets aim at reaching the afterlife which is attained through dying.

5. In a different tone, Mahwee considers love as a reason to die for the sake of the beloved ones while Rossetti does not pay that much care.

6. Rossetti feels more boredom of life than Mahwee, she never leaves the negation of life in her mind whereas Mahwee, as he was a sufi, sometimes sees life as mirage that passes rapidly towards death.

\section{References}

1. Conley, Susan. “'Poet's Right': Christina Rossetti as Anti-Muse and the Legacy of the Poetess", USA. 1994. Print.

2. Harrison, A.H. "Introduction: Christina Rossetti". USA. 1994. Print.

3. Hassan, Ihab. The Problem of Influence in Literary History. USA: American Journal of Aesthetics and Art Criticism, 1955. Print.

4. Mallaa, Ahmadi. "Mahwee and Love, An Anlytical Study". Sulaymaniah. 2018. Print.

5. Muddarress, A \& Karim, Hamay Malla. "The History Of Kurdish Literature". Iran, 2012. Print.

6. Osman, Salar. "Death between Literature \& Philosophy, Mahwee as an Example". Erbil. 2016. Print.

7. Remark, Henry. Comparative Literature: Its Definition and Function. USA: Southern Illinois University Press, 1961.print.

8. Sajadi, Alaadin. History of Kurdish Literature. Sinna: Kurdistan Publishers, 2011.print.

9. Schimmel, Annemarie. Sufism and Tasawwuf in Islam. USA, MCL. 1990. Print.

10.Sleman, Hazhar. Shadow of Meaning. Sulaymanyah. 2018. Print.

11.Thornley, G C, Roberts, G. " An Outline of English Literature". China, Longman. 2013. Print.

12.Yang, O.J. "A Study of Rossetti's Poems on Death", Texas. 1992. Print. 